\title{
Effect of Lower Limb Strength on Falls and Balance of the Elderly
}

\author{
Kang Hee Cho, M.D., Soo Kyung Bok, M.D., Young-Jae Kim, M.D., Seon Lyul Hwang, M.D.
}

Department of Rehabilitation Medicine, School of Medicine, Chungnam National University, Daejeon 301-721, Korea

\begin{abstract}
Objective To assess the effect of lower limb strength on falls and balance in community-dwelling elderly persons by a health status questionnaire, evaluation of lower limb strength and balance.

Method A total of 86 subjects (age 69.8 \pm 5.3 ) were categorized into one of two groups, "Fallers" and "Non-fallers". Thirty one participants who had reported the experience of having fallen unexpectedly at least once in the past year were assigned into the group "Fallers", and the remaining 55 subjects having no fall history in the past year, "Non-fallers". A self-assessment questionnaire was taken. Lower limb strength was measured by a "Chair stand test". Balance was measured by the stability index of the fall risk test protocol of Balance System SD ${ }^{\circledR}$ (Biodex, New York, USA). The differences between the two groups were compared and the correlation between lower limb strength and balance were analyzed.

Results The questionnaire demonstrated no significant differences between two groups. The "Chair stand test" showed a significantly less for the "Fallers" $(\mathrm{p}<0.05)$. The stability index was significantly greater in the "Fallers" group $(\mathrm{p}<0.05)$. There was a moderate negative correlation between the "Chair stand test" and the "Stability index" $(\mathrm{R}=-0.576, \mathrm{p}<0.01)$.

Conclusion This study suggests that the "Chair stand test" is a useful screening process for lower limb strength which correlates to risk for falls and balance in the elderly.
\end{abstract}

Key Words Elderly, Fall, Lower limb strength, Balance

\section{INTRODUCTION}

An elderly fall is recognized as a major health problem. It can cause severe injury, such as: fracture or traumatic brain injury, admission to a facility or even death. ${ }^{1}$ It is

Received July 29, 2011; Accepted March 15, 2012

Corresponding author: Young-Jae Kim

Department of Rehabilitation Medicine, School of Medicine, Chungnam National University, 282 Munhwa-ro, Jung-gu, Daejeon 301-721, Korea Tel: +82-42-280-7811, Fax: +82-42-256-6056, E-mail: yjsjk214@cnuh.co.kr (c) This is an open-access article distributed under the terms of the Creative Commons Attribution Non-Commercial License (http:// creativecommons.org/licenses/by-nc/3.0) which permits unrestricted noncommercial use, distribution, and reproduction in any medium, provided the original work is properly cited.

Copyright $\odot 2012$ by Korean Academy of Rehabilitation Medicine well known that increased age is closely related to the incidence of fall. One third of the people over age 65 have experienced fall and half of the people more than age 80 have reported that they have fallen. ${ }^{2}$ According to a US report, a fall is common among the elderly over $65 ; 1 / 3$ of whom has a fall history and will eventually live with a lengthy medical treatments. ${ }^{3}$ In South Korea, $11 \%$ of the population was 65 and older in 2006, this number has tripled since 1970 when it was $3.1 \%$ of the population (National Statistical Office of South Korea, 2006). Furthermore, this proportion will continue to rise to $29.6 \%$, making falls a major health issue for the elderly. The elderly with a history of falls experience fear due to a possible subsequent fall that could limit their activities and 
mobility due to poor muscle strength. ${ }^{4}$

The known risk factors of fall are age, a previous fall, arthritis, cognitive impairment, dependency for activities of daily living, depression, gait and balance disturbances, medications, muscle weakness and visual and sensory impairments. ${ }^{5,6}$ According to a guideline by the American Geriatrics Society, 2001, the age who have suffered a fall at least once a year would benefit from the timed "Up and Go" (TUG) test. ${ }^{7}$ Elderly men with a history of repetitive falls should undergo an evaluation for: comorbid disorders, difficulties in mobility, gait and balance issues, lower extremity joint function, mental status, neurologic and cardiovascular function, and visual tests. ${ }^{8}$

The "Chair stand test" quickly checks the muscle power of lower extremity more easily than an isokinetic dynamometer without special training or equipment by counting the number of standing and sitting on the chair. Jones et al. ${ }^{9}$ reported that a "30 seconds Chair stand test", counting the number of times a client stands up for 30 seconds, is more reliable than an existing test which checks the time one takes to stand for a total of 5 or 10 times. They also reported that 1-RM (repetition maximum) muscle power test result and " 30 seconds stand up test" have moderate correlation.

The fall risk test protocol of Balance System SD ${ }^{\circledR}$ (Biodex, New York, USA) indicates that the balance ability of subjects as a "Stability index" by measuring changes in center of gravity in mediolateral and anteropsterior directions. Finn et al. ${ }^{10}$ reported that the fall risk test protocol is an available test measuring the balance of the subjects over 50 who have a different abilities of balance.

In this study we are going to check the effect of lower extremity muscle power on balance and fall by doing a survey for elderly dwelling in the community who have made outpatient visits at a university hospital with a history of a fall and physical condition, measurement of lower extremity muscle power and balance index.

\section{MATERIALS AND METHODS}

\section{Subjects}

Eighty-six (43 male, 43 famale) subjects were recruited from outpatient of the university hospital who were over 65. The subjects with other factors that could influence a fall such as: stroke, spinal injury or Parkinson disease were excluded. We define "Fallers" as the 31 subjects with a history of a fall more than once within a recent year and
Table 1. General Characteristics of Subjects

\begin{tabular}{lcc}
\hline \multicolumn{1}{c}{ Characteristics } & Fallers $(\mathbf{n = 3 1})$ & $\begin{array}{c}\text { Non-fallers } \\
(\mathbf{n}=\mathbf{5 5})\end{array}$ \\
\hline Age (years) & $72.1 \pm 5.9$ & $71.7 \pm 5.1$ \\
Gender, male/female & $16 / 15$ & $27 / 28$ \\
Height $(\mathrm{cm})$ & $161.4 \pm 9.3$ & $162.0 \pm 7.9$ \\
Weight $(\mathrm{kg})$ & $62.8 \pm 8.5$ & $62.3 \pm 7.4$ \\
Frequency of fall & $1.8 \pm 1.3$ & 0 \\
\hline
\end{tabular}

Values are means \pm standard deviation

"Non-fallers" as the 55 people who have not fallen within a recent year. Among the "Fallers", 20 subjects reported an experience of one fall, 5 subjects with a fall twice and 6 subjects with more than three falls (Table 1).

\section{Study design}

We carried out a survey for the subjects to evaluate demographic information, fall history, physical condition by checking Short Form Health Survey-36 (SF-36) and physical function. The subjects filled in the questionnaire directly and were given ample opportunity to question to the experimenter at any time. The basic demographic data included: activities of daily living dependency age, height, sex, weight, underlying disease, medication, activity and total number of falls. To assess general the physical condition and physical function, 2 items from SF-36 were quoted. The general physical condition of items were composed 4 questions with 5 rating scale and physical function consists 10 questions with 3 rating scales (Appendix 1). ${ }^{11}$

After completing the questionnaire, the "Chair stand test" was done to evaluate lower extremity muscle power. The subjects were asked to sit on the chair whose back was $40 \mathrm{~cm}$ and settle themselves half of the buttock with straighten back and crossing the wrists in front of chest. And then they would stand up and sit down repetitively foe 30 seconds and count the number (Fig. 1). The tests were conducted 3 times and the results used the averages taken from each test.

To assess the balance function, the falls risk test protocol of Balance System SD ${ }^{\circledR}$ was used and the "Stability index" was calculated. The subjects got on a round 55 cm diameter platform connected to a desktop and monitor with eye opened. For the safety of subjects, they are allowed to hold a handle. Each session lasted of $20 \mathrm{sec}-$ onds, completed a total of 3 times trial and platform was designed to be flexible without fixed state to induce the 

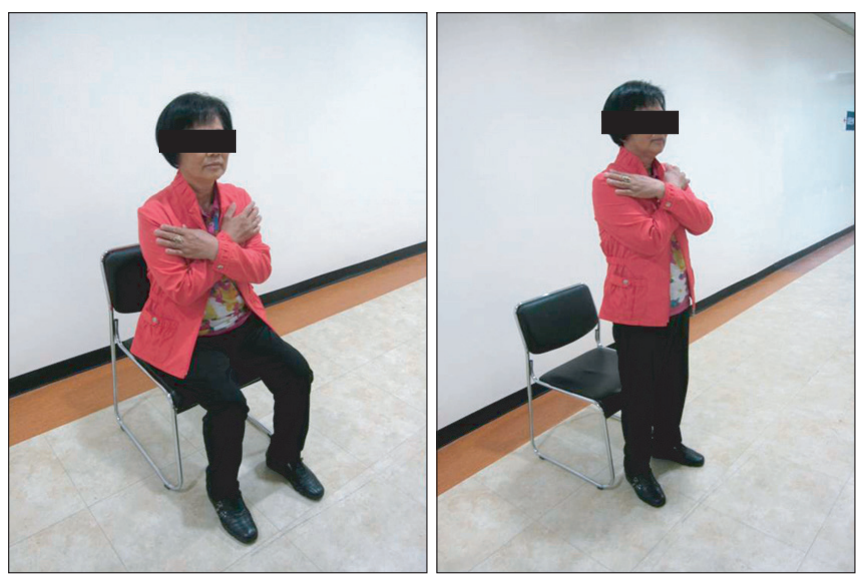

Fig. 1. Chair stand test. change of center of gravity therefore we could evaluate the subjects' dynamic balance function and expressed it as balance measure (Fig. 2). The "Stability index" was calculated by a formula described below (Fig. 2) and higher score means poorer balance function.

\section{Analysis}

We compared the results from general physical condition, results from the questionnaires checking physical function, the outcome of the "Chair stand test" and the "Stability index" with "Faller" between "Non-fallers". And to assess the correlation between lower extremity strength and balance function, a correlation analysis was done between the "Chair stand test" and the "Stability index" in all the subjects with "Fallers" and "Non-fallers".

(A)

\begin{tabular}{|ccc|}
\hline & Actual & STD \\
& Score & Dev. \\
Overall "Stability index": & 1.7 & 2.80 \\
\hline
\end{tabular}

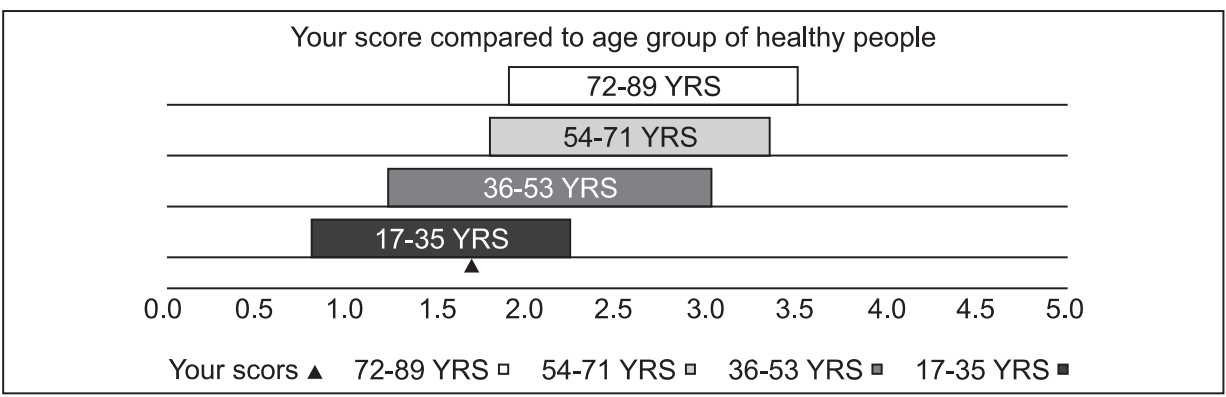

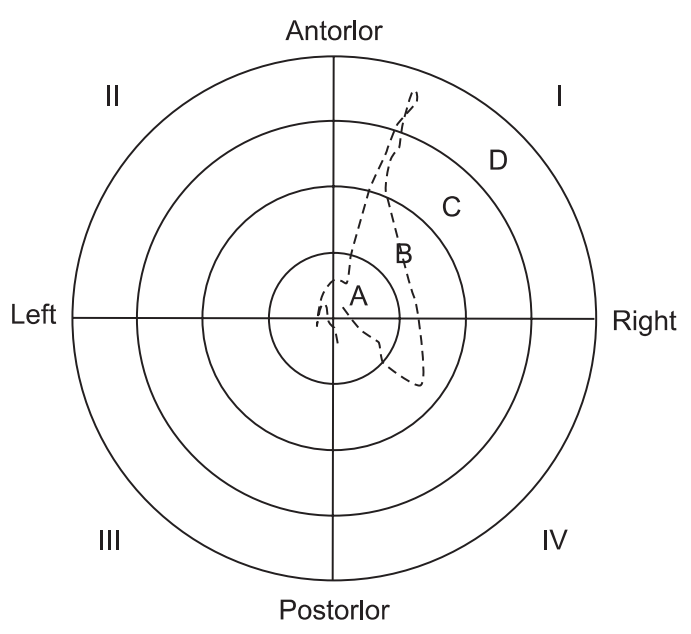

(B)

$$
\begin{aligned}
\text { Stability index } & =\sqrt{\frac{\Sigma(0-X)^{2}+\Sigma(0-Y)^{2}}{\text { Numbers }}} \\
& * X: \text { Mediolateral movement of center of gravity } \\
& * Y \text { : Anteroposterior movement of center of gravity }
\end{aligned}
$$

Fig. 2. Fall risk test protocol of Balance System SD ${ }^{\circledR}$ (Biodex, New York, USA). (A) Report of fall risk test protocol. (B) Formula to calculate "Stability index". YRS: Years. 


\section{Statistical analysis}

Statistical analysis was done with SPSS 18.0 Korean statistical program (SPSS Inc., Chicago, IL, USA). For the comparison of the results of "Fallers" and "Non-fallers", an independent t-test was done. The Pearson correlation analysis was used to evaluate the correlation between lower extremity strength and balance function. A statistically significant $\mathrm{p}$-value is below 0.05 in independent $\mathrm{t}$ test and below 0.01 in Pearson correlation analysis. In the purpose of checking usefulness of prediction of fall and calculating the cut-off value of "Chair stand test" and fall risk test protocol of Balance System $\mathrm{SD}^{\circledR}$, we checked the ROC curve.

\section{RESULTS}

\section{Comparison of "Fallers" and "Non-fallers"}

According to the questionnaires, scores of general

Table 2. Results of Questionnaire, and Lower Limb Strength and Balance

\begin{tabular}{lccc}
\hline & $\begin{array}{c}\text { Fallers } \\
(\mathbf{n = 3 1})\end{array}$ & $\begin{array}{c}\text { Non-fallers } \\
(\mathbf{n = 5 5 )}\end{array}$ & p-value \\
\hline Questionnaire & & & \\
\hline GH & $40.6 \pm 16.7$ & $41.4 \pm 17.8$ & 0.853 \\
PF & $67.4 \pm 21.8$ & $72.6 \pm 17.4$ & 0.206 \\
Chair-stand test & $10.9 \pm 4.4$ & $16.2 \pm 4.9$ & $0.001^{*}$ \\
Stability index & $3.5 \pm 1.3$ & $2.2 \pm 0.9$ & $0.001^{*}$
\end{tabular}

Values are means \pm standard deviation

GH: General health item of SF-36, PF: Physical function item of SF-36

${ }^{*} \mathrm{p}<0.05$ with independent t-test

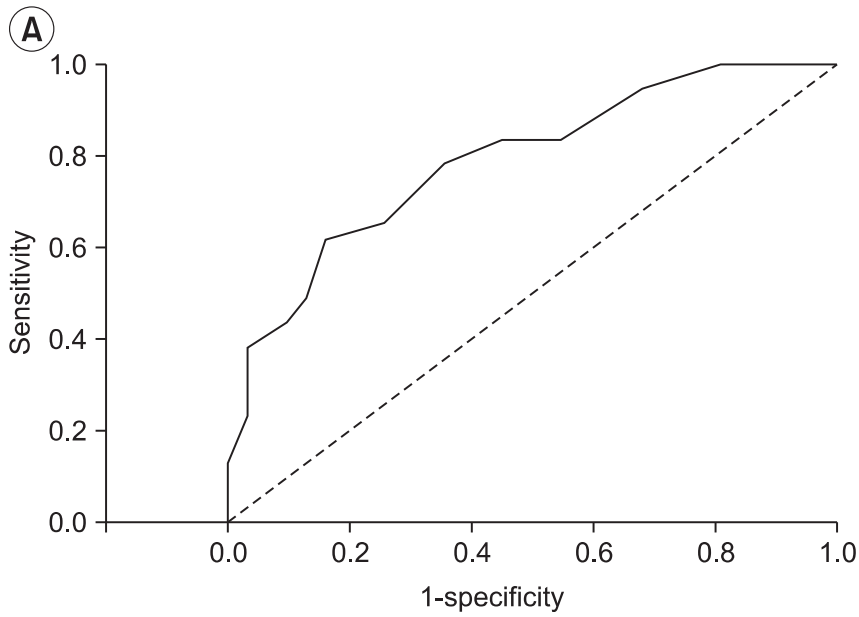

physical health in "Fallers" were 40.6 \pm 16.7 and there are not significantly different from "Non-fallers" whose scores were $41.4 \pm 17.8$. Also scores checked by the questionnaires asking physical function had no significant difference between "Fallers" (67.4 \pm 21.8$)$ and "Non-fallers" $(72.6 \pm 17.4)$. In the "Chair stand test", scores of "Fallers" were significantly lower than "Non-fallers" $(\mathrm{p}<0.05)$

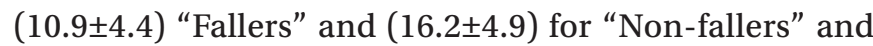
balance measures were significantly higher in "Fallers" $(3.5 \pm 1.3)$ than "Non-fallers" $(2.2 \pm 0.9)(\mathrm{p}<0.05)$ (Table 2).

\section{Correlation between "Chair stand test" and "Stability} index"

"Chair stand test" and "Stability index" showed moderate negative correlation among all the subjects including "Fallers" and "Non-fallers". This result means that higher scores in "Chair stand test" are correlated with lower

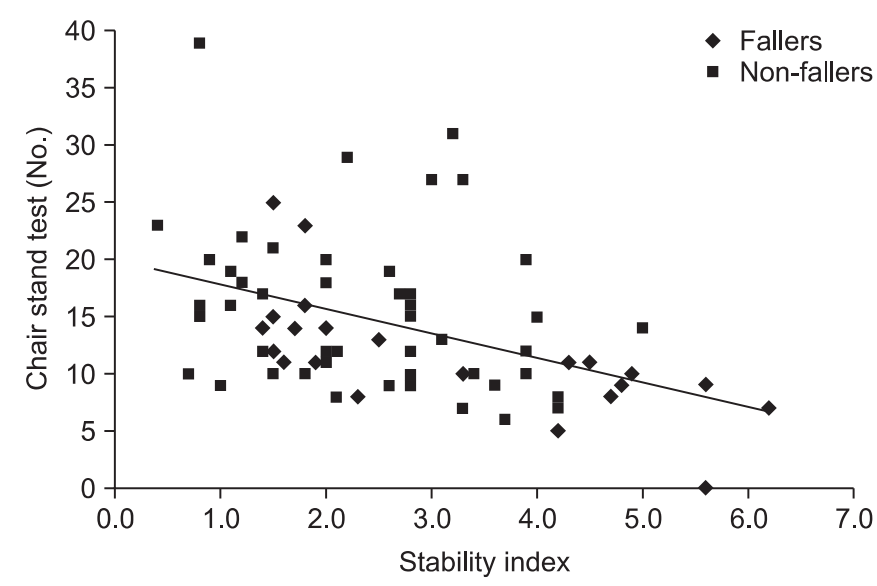

Fig. 3. Correlation between "Chair stand test" and "Stability index".

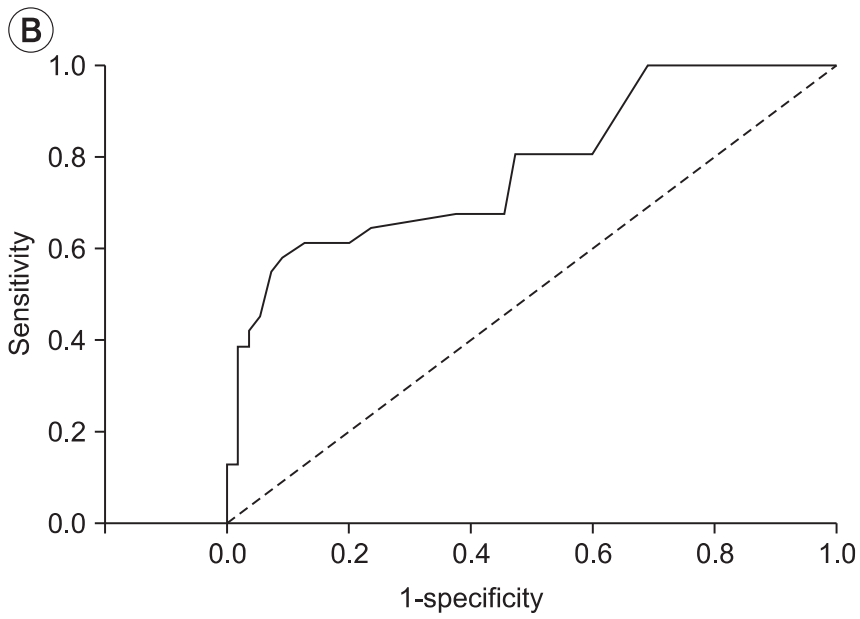

Fig. 4. ROC curve of "Chair stand test" and "Stability index". (A) Chair stand test. (B) Stability index. 
"Stability index" (R=-0.576, p<0.01) (Fig. 3).

\section{ROC curve of "Chair stand test" and balance measures}

$\mathrm{A}$ area below curve was 0.789 , $\mathrm{p}$-value was under 0.05 of ROC curve of "Chair stand test" and these mean a fair usefulness in the test $(\mathrm{p}<0.05,95 \% \mathrm{CI}=0.69-0.89)$ and cut-off value, that was set up at 15 times was checked $61.8 \%$ sensitivity and $83.9 \%$ specificity. For the balance measure, area under curve was 0.779 , $p$-value under 0.05 and showing a fair usefulness in the test $(\mathrm{p}<0.05,95 \%$ $\mathrm{CI}=0.67-0.88$ ). The cut-off value was checked $61.3 \%$ sensitivity and $87.3 \%$ specificity established at 3.05 (Fig. 4).

\section{DISCUSSION}

Fall prevention is important in geriatric medicine. Evaluation of risk factors for a fall is necessary to select a high risk group who can be the control group for programs on fall prevention. In this study, "Fallers" have significantly less lower extremity strength and balance function than "Non-fallers". Several studies reporting the association between balance function and fall support our study. ${ }^{12-15}$

Melzler et al. ${ }^{12,13}$ evaluated the balance function of the elderly in 4 circumstances, with opened eyes and closed eyes using a force platform, with feet apart wide and narrow. In the situation with feet apart narrow, "Fallers" had poorer balance compared to "Non-fallers" because of the formers' significantly increased movement of center of center of gravity to mediolateral direction. Caterino et al. ${ }^{14}$ evaluated the balance function for patients visiting an emergency room by using the TUG test and the force platform. Even though there was no significant association between falls with two tests, the test using the force platform was sensitive to assess falls that occurred within 1 week and the TUG test was useful in checking a fall happened 6 months before. As the former studies, they used force platform to check the movement of the center of gravity in the anteroposterior or mediolateral direction or Berg Balance Scale (BBS), TUG test to assess balance function. But the BBS is time consuming and result of test using force platform is difficult to be understood by subjects.

Therefore this study assesses the balance function by using fall risk test protocol of Balance System SD $^{\circledR}$. The strengths of this protocol is that the time to evaluate is short because the total 3 sessions were conducted over
20 seconds and the results are displayed as balance measures which are easy to compare with the control group and also easy to explain to the subjects. We can identify the association between balance function and fall by checking the significantly higher Stability index in "Fallers" than "Non-fallers" ( $\mathrm{p}<0.05)$.

According to the formal studies, there were no definite conclusion in the association between lower extremity strength and fall. Melzer et al. ${ }^{12}$ reported that the strength of an ankle and a knee measured by an isokinetic dynamometer is not significantly different in "Fallers" and "Non-fallers" even though "Fallers" have decreased strength. Skelton et al. ${ }^{16}$ also found that 20 women who had fallen before had no significant decrease in lower extremity strength than 15 women with no history of fall. But Wolfson et al. ${ }^{17}$ and Whipple et al ${ }^{18}$ reported that "Fallers" have significantly decreased lower extremity strength when examined by isokinetic dynamometer than "Non-fallers".

In this study we assessed the lower extremity strength by a "Chair stand test" and concluded that a decrease in lower extremity strength is associated with increased risk for fall according to result of significantly decreased outcome in "Fallers". The "Chair stand test" is a simple test that can be done in short time without any other equipment or specific skill. Therefore it can be the useful screening test to predict the risk of fall in the elderly.

We found that there is moderate negative association between "Chair stand test" and "Stability index" in the association analysis $(\mathrm{R}=-0.576, \mathrm{p}<0.01)$. Increased Stability index means a poorer balance function. This study demonstrated that increased lower extremity strength is associated with better balance function. The ROC curve for the "Chair stand test" and "Stability index" showed that the area under the curve was $0.789,0.779$ each and $\mathrm{p}$-value was lower than 0.05 . These results showed that these test are useful in predicting falls in the elderly and that the "Chair stand test" must be included as the screening test for falls risk evaluation for the elderly. In the "Chair stand test", the sensitivity was $61.8 \%$ and specificity was $83.9 \%$ when we set the cut off value as 15 times. In the "Stability index", if the cut off value was 3.05 then sensitivity was $61.3 \%$ and specificity was $87.3 \%$. More subjects are needed to verify this result but these results can be used to predict the risk of a fall.

It is also known that comorbid disorders which can 
influence balance are risk factors in the elderly. ${ }^{19}$ In this study we tried to control this factor and reduce the errors by excluding subjects with disease in central nervous systems like spinal cord injury, stroke, and Parkinson's disease which can influence balance and cause urinary incontinence.

Cumming et al. ${ }^{20}$ reported that 3 items with physical function, mental health and physical pain from Falls Efficacy Scale (FES) and SF-36 have significant correlation. But in this study 2 items with general physical status and physical function from SF-36 have higher scores in "Fallers" than "Non-fallers" but are not significant. All 5 questions about the general health status were subjective and the 5 rating scale system made it difficult to answer. Questions about physical function have a limitation that they can be difficult to measure the muscle power or balance power specifically. These limitations make the questionnaire fail to show the significant result in evaluating the risk of a fall and other further tests need to be developed that assess the lower extremity strength or balance function.

We have to acknowledge some limitations of this study. First, for the safety of the subjects, all of them carried out the test with holding in the strap. This can affect the result by adding the stabilization of upper extremity function. In future research this should e corrected. Second, existing reports performed an examination 5 times and used their average value to assess balance function using Balance System $\mathrm{SD}^{\circledR 10}$ but we executed the examination 3 times. Even though the standard deviation was not big, it could affect the reliability of the study. Third, we only recruited the subjects who visited the hospital. The elderly who live in the community without specific disease must be included in a future study. Finally, there is a lack in the analysis of association between "Chair stand test" and manual muscle testing which has been used widely before. We also did not include a test that must be done to assess the balance in sitting position thus we failed to evaluate the balance function in sitting position. In additional future studies, more specific tests such as manual muscle testing or an isokinetic dynamometer must be done to compare the result and to assess the balance function in sitting position. The "Chair stand test" is still under investigation to figure out the exact mechanisms of the test and these results can support the association between the test and the risk for a fall.

\section{CONCLUSION}

We executed the questionnaires asking about the general health status and physical function and "Chair stand test" to assess lower extremity strength and "Stability index" of fall risk test protocol of Balance System SD ${ }^{\circledR}$ to check the balance function for the aged over 65 who visited as an outpatient of university hospital. The "Chair stand test" showed that "Fallers" have significantly lower score and "Fallers" are significantly higher in the "Stability index". The "Chair stand test" and the "Stability index" have a moderate negative association so we can conclude poorer lower extremity strength is associated with higher risk of fall. Both the "Chair stand test" and the "Stability index" showed fair the area under curve and had a significance that proved the useful in the prediction of a fall. The "Chair stand test" is simple and doesn't need a skilled examiner or specific equipment without limitation in the space than the measurement of move of center of gravity by using the force platform or isokinetic dynamometer, so that it can be the useful screening test to predict the fall of the old. In the future studies, errors must be reduced, including the community dwelling healthy elderly and compare the existing test.

\section{REFERENCES}

1. Sattin RW, Lambert Huber DA, Devito CA, Rodriguez JG, Ros A, Bacehelli S, Stevens JA, Waxweiler RJ. The incidence of fall injury events among the elderly in a defined population. Am J Epidemiol 1990; 131: 10281037

2. Tinetti ME, Williams CS. Falls, injuries due to falls, and the risk of admission to a nursing home. $\mathrm{N}$ Engl J Med 1997; 337: 1279-1284

3. Sterling DA, O'Connor JA, Bonadies J. Geriatric falls: injury severity is high and disproportionate to mechanism. J Trauma 2001; 50: 116-119

4. Tinnetti ME, Speechly M. Prevention of falls among the elderly. N Eng J Med 1989; 320: 1055-1059

5. Tinetti ME, Speechly M, Ginter SF. Risk factors for falls among elderly persons living in the community. $\mathrm{N}$ Eng J Med 1988; 319: 1701-1707

6. Capmbell AJ, Borries MJ, Spears GF. Risk factors for falls in a community-based prospective study of people 70 years and older. J Gerontol 1989; 44: M112-117 
7. Podsiadlo D, Richardson S. The timed "Up \& Go": a test of basic functional mobility for frail elderly persons. J Am Geriatr Soc 1991; 39: 142-148

8. Guideline for the prevention of falls in older persons. American Geriatrics Society, British Geriatrics Society, and American Academy of Orthopaedic Surgeons Panel on Falls Prevention. J Am Geriatr Soc 2001; 49: 664-672

9. Jones CJ, Rikli RE, Beam WC. A 30-s chair-stand test as a measure of lower body strength in communityresiding older adults. Res Q Exerc Sport 1999; 70: 113119

10. Finn JA, Alvarez MM, Jett RE, Axtell RS, Kemler DS. Stability performance assessment among subjects of disparate balancing abilities. Med Sci Sports Exerc 1999; 31: S252

11. Ware JE Jr, Scherbourne CD. The MOS 36-item shortform health survey (SF-36). I. conceptual framework and item selection. Med Care 1992; 30: 473-483

12. Melzer I, Benzuya N, Kaplanski J. Postural stability in the elderly: a comparison between fallers and nonfallers. Age Ageing 2004; 33: 602-607

13. Melzer I, Kurz I, Oddsson LI. A retrospective analysis of balance control parameters in elderly fallers and non-fallers. Clin Biomech 2010; 25: 984-988

14. Caterino JM, Karaman R, Arora V, Martin JL, Hiestand
BC. Comparision of balance assessment modalities in emergency department elders: a pilot cross-sectional observational study. BMC Emerg Med 2009; 9: 19-25

15. Maki BE, Holliday PJ, Topper AK. A prospective study of postural balance and risk of falling in an ambulatory and independent elderly population. J Gerontol 1994; 49: M72-84

16. Skelton DA, Kennedy J, Rutherford OM. Explosive power and asymmetry in leg muscle function in frequent fallers and non-fallers aged over 65. Age Ageing 2002; 31: 119-125

17. Wolfson L, Judge J, Whipple R, King M. Strength is a major factor in balance, gait, and the occurrence of falls. J Gerontol A Biol Sci Med Sci 1995; 50: 64-67

18. Whipple RH, Wolfson LI, Amerman PM. The relationship of knee and ankle weakness to falls in nursing home residents: an isokinetic study. J Am Geriatr Soc 1987; 35: 13-20

19. Lawlor DA, Patel R, Ebrahim S. Association between falls in elderly women and chronic diseases and drug use: cross sectional study. BMJ 2003; 327: 712-717

20. Cumming RG, Salkeld G, Thomas M, Szonyi G. Prospective study of the impact of fear of falling on activities of daily living, SF-36 scores, and nursing home admission. J Gerontol A Biol Sci Med Sci 2000; 55: M299-305 
낙상 위험성 측정을 위한 자가 설문지

\begin{tabular}{|c|c|c|c|c|c|c|}
\hline \multicolumn{7}{|l|}{ I. 일반적 정보 } \\
\hline 성함 & \multicolumn{4}{|r|}{ 연령/성별 } & & \\
\hline 키 & \multicolumn{4}{|r|}{ 몸무게 } & & \\
\hline 생년월일 & \multicolumn{4}{|r|}{ 연락처 } & & \\
\hline \multicolumn{7}{|l|}{$\begin{array}{c}\text { 진단 받고 계신 } \\
\text { 질병 }\end{array}$} \\
\hline \multicolumn{7}{|l|}{ 복용 중인 약 } \\
\hline 일상생활자립도 & \multicolumn{2}{|c|}{ ㄷ독립적 } & 때때로 도움 & 움 필요 & \multicolumn{2}{|c|}{ ㅁ전적으로 도움 필요 } \\
\hline 활동성 & \multicolumn{2}{|c|}{$\square$ 활동적 } & 때때로 활동 & 동적 & \multicolumn{2}{|c|}{ 대체로 실내생활 } \\
\hline \multicolumn{7}{|c|}{ 지난 1년 동안에 넘어진 횟수가 어느 정도입니까? _— 번 } \\
\hline \multicolumn{7}{|c|}{ II. 자가 진단 설문 } \\
\hline \multicolumn{7}{|c|}{ 1. 일반적 건강상태 } \\
\hline \multicolumn{7}{|c|}{ 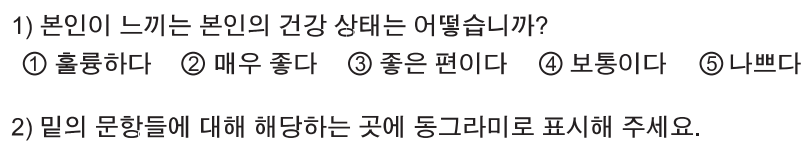 } \\
\hline & & 매우 맞다 & 맞는 편임 & 잘 모른다 & 아닌 편임 & 매우 아님 \\
\hline $\begin{array}{l}\text { 나는 다른 사람 } \\
\text { 비해 자주 아프 }\end{array}$ & & 1 & 2 & 3 & 4 & 5 \\
\hline $\begin{array}{l}\text { 나는 내가 아는 } \\
\text { 보다 더 건강하 }\end{array}$ & & 5 & 4 & 3 & 2 & 1 \\
\hline $\begin{array}{l}\text { 내 건강은 지금 } \\
\text { 나빠질 것이다 }\end{array}$ & & 1 & 2 & 3 & 4 & 5 \\
\hline 내 건강은 훌륭 & 하다 & 5 & 4 & 3 & 2 & 1 \\
\hline
\end{tabular}

2. 신체적 기능상태

1) 밑에 주어진 항목들은 응답자 분이 일상생활에서 하는 활동들입니다. 현재 본인의 건강이 이러한 활동들을 방해하는 것이 있으면 해당 항목에 동그라미로 표시해 주세요.

\begin{tabular}{|c|c|c|c|}
\hline 활동 & $\begin{array}{c}\text { 네, 많이 } \\
\text { 방해합니다. }\end{array}$ & $\begin{array}{l}\text { 네, 약간 } \\
\text { 방해합니다. }\end{array}$ & $\begin{array}{l}\text { 아니오, 전혀 } \\
\text { 상관없습니다 }\end{array}$ \\
\hline $\begin{array}{l}\text { 정력적인 활동들 (달리기, } \\
\text { 무거운 물건 들기, 거친 스포츠 } \\
\text { 활동 참여하기) }\end{array}$ & 1 & 2 & 3 \\
\hline $\begin{array}{l}\text { 중간정도 활동들 (책상 밀기, } \\
\text { 볼링치기, 골프하기) }\end{array}$ & 1 & 2 & 3 \\
\hline 식료품 들거나 나르기 & 1 & 2 & 3 \\
\hline 계단 몇 층 올라가기 & 1 & 2 & 3 \\
\hline 계단 한 층 올라가기 & 1 & 2 & 3 \\
\hline $\begin{array}{l}\text { 허리 구부리기, } \\
\text { 선 채로 무릎에 손얹기 }\end{array}$ & 1 & 2 & 3 \\
\hline $1,500 \mathrm{~m}$ 이상 걷기 & 1 & 2 & 3 \\
\hline $400 \mathrm{~m}$ 정도 걷기 & 1 & 2 & 3 \\
\hline $100 \mathrm{~m}$ 정도 걷기 & 1 & 2 & 3 \\
\hline 스스로 목욕하거나 옷 입기 & 1 & 2 & 3 \\
\hline
\end{tabular}

Appendix 1. A self-assessment questionnaire including basic information of subject, frequency of fall, and selected items from SF-36. SF-36: Short Form Health Survey-36. 